\title{
$\underline{\text { Towards a sociology of risk work: a narrative review and synthesis }}$
}

\section{Nicola K. Gale*, University of Birmingham}

Gareth M. Thomas, University of Cardiff

Rachel Thwaites, Canterbury Christ Church University

Sheila Greenfield, University of Birmingham

Patrick Brown, University of Amsterdam

*Corresponding Author: Health Services Management Centre, School of Social Policy, University of Birmingham.

A: Park House, 40 Edgbaston Park House, Birmingham, B15 2RT.

T: +44(0) 1214149089

E: ‥gale@bham.ac.uk, n.k.gale@gmail.com

\section{ABSTRACT}

In this article we define the concept of 'risk work', which aims to make visible working practices to assess or manage risk in order to subject these practices to sociological critique. This article reviews and synthesizes existing published literature in the field of health to identify components of risk work: 1) translating risk into different contexts; 2) minimizing risks in practice, and; 3) caring in the context of risk. We argue that these three components of risk work raise important tensions for workers that have been inadequately explored in the literature to date. We propose that future research should additionally focus on practitioner subjectivity and identity in risk work. In addition, we argue that comparative research - across type of risk and different contexts - and methodological and theoretical diversity would enhance this emerging field of research. 


\section{INTRODUCTION}

"Reconciling and integrating the one-on-one, doctor-patient relationship of clinical medicine with population-based reasoning and action is [a] long-standing problem in modern medicine, fraught with uncertainty ... It is not only a cognitive problem, but one that entails deep role conflicts ... between 'clinical loyalty' and 'social purpose'"' (Fox 2002: 244).

It has been nearly 30 years since the emergence of a literature on the 'risk society' (Giddens 1991, Beck 1992, Beck 2000) yet, despite a burgeoning field of the sociology of risk and its application to health, including a recognition of the need to understand risk in the context of everyday lives (Lupton and Tulloch 2002, Zinn 2008), the focus of existing research on risk in health and health care has tended to be placed either on patient experiences of uncertainty or on the governance of risk by organisations. In contrast, the impact of risk on the nature and experiences of healthcare work remain relatively neglected. We propose that 'risk work', defined as working practices framed by concepts of risk - a concept synthesizing and developing insights from the sociology of risk and uncertainty and the sociology of work and employment - could be a useful way to develop our understanding of these practices.

The question of 'risk work' has significant implications for public health policy. The sustainability problems associated with a cure-focused health system and the need for a stronger approach to managing health risks has been emphasised internationally. In the UK, for instance, the government has been urged to develop prevention services 'on an industrial scale' (Secretary of State for Health 2008) and the recent Five Year Forward View stated: 'The future health of millions of children, the sustainability of the NHS, and the economic prosperity of Britain all now depend on a radical upgrade in prevention and public health' (NHS England 2014: 9). However, it is unclear whether these policy aspirations have been met with appropriate resources and we know little of those at the 'front line' of this work, who are undertaking activities to identify or manage health risks, such as screening for diseases, prescribing preventative medication or providing dietary advice. 
In this article, we review an emerging field of research on healthcare workers who assess and manage health risks as part of their daily practice. First, we provide a background to an emerging literature relevant to the study of risk work and make a case for grouping apparently diverse professionals and healthcare workers together for analysis; second, we describe our narrative review and synthesis methodology; third, we summarise the articles reviewed in terms of empirical focus, methodology, and theoretical perspectives; fourth, we present the findings of our synthesis by identifying components of everyday work for this group and the tensions and challenges faced by workers. We argue that despite the literature addressing some of the practices relevant to risk work, there is very little research addressing embodied identity or subjectivities of workers, or research that introduces comparative analysis. Finally, we outline our suggestions for future directions of research in the field of risk work.

\section{BACKGROUND}

Considerations of risk and risk management have proliferated across public sector organisations (Kemshall 2002, Power 2004), particularly in healthcare where the use of risk management to deal with uncertainty has been understood as reorienting the underlying format of professional work (Flynn 2002) and public health interventions (Petersen and Lupton 1996). Significant attention has been focused upon policy logics, organisational dynamics and the governance of risk (Castel 1991, Hood, Rothstein et al. 2001, Horlick-Jones 2005, Rothstein 2006, Alaszewski and Brown 2007), as well as the diffuse power dynamics associated with risk and their varied and sometimes unintended effects in reshaping patients' and publics' subjectivities (Davison, Smith et al. 1991, Petersen 1997, Lupton and Tulloch 2002, Henwood, Pidgeon et al. 2011, Järvinen 2012). Where the focus has been on experiences of risk, it tends to be from the perspective of patients/clients rather than those delivering a service (Anderson 1999, Hallowell 1999, Williams, Sandall et al. 2005, Gillespie 2012, Boardman 2014). For example, there is a wealth of literature on parents' experiences of prenatal screening for Down's syndrome, yet whilst some studies explore parents' interactions with professionals (Williams, Alderson et al. 2002, Williams, Alderson et al. 2002, McCourt 2006, Pilnick 2008, Tsouroufli 2011, Pilnick and Zayts 2012, Thomas 2015, Thomas and Latimer 2015), research on the everyday work practices of involved professionals generates an undersized literature (Thomas 2014). 
It has been recognised that uncertainty, and the associated search for certainty, is a central characteristic of healthcare work (Fox 1980, Fox 2002). Renée Fox has argued that changes over recent decades in medicine have reconfigured the uncertainties that professionals and the public may face. These include the re-emergence of infectious diseases, such as HIV or Ebola, as a major threat to public health, the enduring health inequalities in chronic disease (despite policies designed to tackle them) and the growth of predictive technologies, such as screening and genetic testing (see also e.g. Timmermans and Buchbinder 2010). In addition, changing cultural views, particularly in relation to disability, are affecting the terms of many medical debates. Finally, and perhaps most saliently to our present concern with 'risk work', Fox explores the growing commitment within the medical field to evidence-based medicine (EBM). She argues that this produces 'epistemological uncertainty', that is, uncertainty about the 'nature of good clinical research, good clinical practice and the relationship between them' (Fox 2002: 245). At a clinical level, EBM seems to provide clinicians with a level of certainty - with the notion of 'best evidence' available - from which to advise and act. However, Armstrong (2007) argues that while EBM claims to have reduced indeterminacy, it has instead shifted the 'problem' of uncertainty to a wider policy arena that involves interpreting evidence.

Working with health risks is not just the domain of the health professional; indeed, the need for professionals in an era of EBM is becoming increasingly unclear. Jamous and Pelloille's (1970) classic theory of the professions stressed the importance of indeterminacy, and clinical expertise, rather than technical knowledge which could be administered by lower status workers. The rise of EBM - and its drive for consistent application of externally produced knowledge - has introduced new complexities. On the one hand, guidelines can enable a division of labour, whereby lower status professionals, such as pharmacists, nurses or other workers could administer preventative interventions or treatments on the basis of predetermined risk thresholds. Yet on the other, technicality has been used by some professional groups, such as midwives or doctors, to enhance their standing vis a vis those workers, such as doulas or complementary therapists, who do not engage with EBM (Traynor 2009). The application of risk logics means that many more individuals are 'at risk' than could possibly be dealt with by a limited professional workforce. Accordingly moves have been made to engage 
less highly qualified and less expensive workers. Similarly, there have been arguments to shift as far as possible the locus of work and responsibility towards members of the public. There has been a substantial rise internationally of the use of community health workers (Johnson, Noyes et al. 2013, Singh and Chokshi 2013, Singh and Sachs 2013) and of peer support workers, such as 'expert patients' (Bodenheimer, Lorig et al. 2002, Lorig 2002, Lewin, MunabiBabigumira et al. 2010, Snow, Humphrey et al. 2013).

Concepts from the sociology of work provide a useful lens through which to make sense not only of the actual nature of the work carried out but also the socio-economic conditions within which it takes place. Building upon seminal work on the social organisation of medical work (Strauss, Fagerhaugh et al. 2014[1985]), relevant recent developments in the sociology of work highlight the changing nature of work, including the blurring of boundaries between paid and unpaid/voluntary work, the embeddedness of work in other social relations and the socioeconomic, spatial and temporal dimensions of work (Pettinger, Parry et al. 2006) and the implications of embodiment to work (Wolkowitz 2006), including in the field of health (Brown, Alaszewski et al. 2011, Gale 2011, Twigg, Wolkowitz et al. 2011).

While sociological studies of risk and uncertainty have tended to overlook an explicit focus on risk work, they have nevertheless raised a number of features which are germane to its study. Horlick-Jones (2005) is the only scholar previously to refer to 'risk work' as a specific concept and paints a useful picture of the organisational dynamics and pressures which bear upon professionals/workers, while emphasising questions regarding the pragmatics of risk work of how it 'gets done'. Studies have noted the significant uncertainties faced by healthcare professionals, on the one hand, and the organisational demands for accurate prediction and screening, on the other (Warner and Gabe 2004), with professionals experiencing significant tensions and stress in the midst of this (Scamell 2011, Brown and Calnan 2015). In many cases, however, the foci of these research approaches have been on wider social and organisational processes, outcomes or patient experiences and not on the healthcare work and workers themselves. Below we develop a critical review of the emerging literature on the everyday practices and experiences of health care professionals and workers engaged in assessing and managing physical and mental health risks. 


\section{METHODS}

We undertook a narrative review and synthesis of the literature focusing on the nature and context of risk work in health, and the experiences and perceptions of workers. Our inclusion criteria were:

- empirical or theoretical article published in a journal, book or grey literature;

- in English, or translation available;

- $\quad$ published in or after 1980;

- sociological or social science perspective;

- focus on healthcare practitioners (HCPs) (including professionals and/or trained lay people) and

- focus on disease prevention or health promotion related to mental and/or physical health (including interface with social care).

Given the emergent nature of the field, our goal was to access as many articles as possible but our database searches turned up few results, and in the end we adopted a hand-searching approach. Initially our searching included search terms agreed through discussion with the whole team, which were used to search several databases: Cochrane EPOC Group Specialised Register, The Cochrane Library, MEDLINE (OVID), EMBASE (BIDS or OVID), ECONLIT, Health Economic Evaluations Database (HEED), Health Systems Evidence Database, and TRIP Database. These databases were chosen as the most relevant to our topic and most likely to provide the widest range of results. However, despite continued discussion and refinement of the search terms, these initial searches produced very few useful results so we decided hand-searching would produce much more focused results and, as a team, decided on which journals to search. The following journals were hand searched (2010-2015): Health, Risk, and Society; Health Sociology Review; Medical Anthropology; Medical Anthropology Quarterly; Social Theory and Health; Sociology of Health and Illness; The International Journal of Communication and Health. Some targeted searches were carried out in Community Development; Journal of Community Health; Social Science and Medicine; Sociology; Work, Employment, and Society; Qualitative Health Research; Health: An International Journal. Alongside these journal searches, the specialist library at the Health Services Management Centre, University of Birmingham carried out a further search using the databases listed 
above, with refined search terms which produced further results. A Google Scholar search was run using 'mental health prevention', as little on mental health was emerging from the other searches. After further discussion of the resulting literature list, two final Google Scholar searches were run on 'dental hygienists' and 'community pharmacists'.

The final list (see Table 1) may not be exhaustive, but provides a strong indication of where trends in literature in this area are and where there are gaps. By iteratively returning to our search strategies, discussing, adapting, and changing them as necessary, as well as using supplementary searching to check our initial results, we would argue that we have produced a wide-ranging, informative, and representative review of the current literature. We did not consider risk work in other non-health fields and this could be a topic for future review or extension of theoretical investigations on risk work.

Data extraction was carried out covering key information about the article (author, date of publication, title, academic discipline, keywords, setting, type of HCP, type of health risk, methods, theoretical framework, and key findings). In addition, for each paper, building on Schutz's (1972) concepts, we summarized the 'first order sense-making' (descriptive data about participants' own interpretations and experiences) and 'second level sense-making' (theoretical and critical interpretation by the authors of the articles). To synthesize the literature, we identified types of work that were reported by the authors and expressed in gerund form (see Table 1).

\section{OVERVIEW OF THE LITERATURE}

The literature predominantly emerged from the UK, Canada, Australia, and the United States. This is in part because we only accessed English language articles but may also reflect the interest in preventative healthcare in these national contexts. The most commonly studied professionals and healthcare workers were nurses ( $n=19$ articles), specialist doctors $(n=17)$, general practitioners/family physicians $(n=14)$, midwives $(n=9)$, community health workers (such as health or cultural educators, community facilitators, or AIDS awareness workers $(n=6))$, social workers $(n=5)$, managers or programme directors $(n=4)$, sonographers $(n=4)$, clinical psychologists $(n=4)$, CAM practitioners such as chiropractors, herbalists or yoga 
instructors $(n=4)$, health visitors $(n=3)$, dieticians $(n=3)$, public health scientists or doctors $(n=2)$. Other articles studied: genetic counsellors, nursing auxiliaries, doulas, chaplains, personal trainers. In a number of articles it was not always clear exactly which type of workers were involved. The most common health risks being managed by workers were related to pregnancy and birth $(n=16)$, non-communicable diseases, such as cardiovascular disease, diabetes and cancer $(n=8)$, communicable diseases, such as HIV, BSE or Dengue fever $(n=8)$ and mental health $(n=7)$. Health inequalities in relation to gender, ethnicity or 'race' and socio-economic status or class were also considered in some of the articles.

\section{Theoretical and Methodological Approaches}

Working with health risks is distinctive in its application of particular frameworks of probabilistic knowledge in workers' handling of uncertainty. By far the most common theoretical approaches used were those that directly interrogated the nature of (risk) knowledge frameworks and the power relations these are predicated upon. Foucauldian themes are thus ubiquitous, either highly explicitly in analyses of biopower and governmentality (Frohlich, Mykhalovskiy et al. 2012, Mishra and Graham 2012), more implicitly such as in denoting the power of texts to shape defensive clinical practice (Warner 2006), or via a range of Foucauldian-influenced theorists such as Rose (Villaamil 2014), Castel (Godin 2004), or Hacking (Olin Lauritzen and Sachs 2001). Such approaches are often combined with other theories, not least related post-structuralist perspectives, in deconstructing the workings of power via knowledge. Feminist (Nissen 2013), post-colonial (Darroch and Giles 2015) and actor-network-theory (Wardlow 2012) influences are apparent here.

A second theoretical tendency relates to various ways of understanding problems of uncertainty and attempts to overcome this. Beck and Giddens are often referred to in considering a heightened awareness of and sensitivity to uncertainty in broader society (Green, Thompson et al. 2002, Scamell and Alaszewski 2012), with the likes of Heyman (Scamell 2011, Burton-Jeangros, Cavalli et al. 2013), Rothstein (Brown and Calnan 2013) and Fox (Griffiths, Green et al. 2006) used to frame problems, dynamics and pressures of uncertainty at an organisational level. How uncertainty and organisational pressures are 
grappled with by individual professionals is often analysed through various classic social theories such as symbolic interactionism (Hall, Tomkinson et al. 2012), ethnomethodology (Thomas 2015), phenomenology (Wood, Prior et al. 2003) and Bourdieusian practice theory (Broom, Broom et al. 2014). Individual practices and experiences of workers are also framed in terms of health beliefs (Bean and Catania 2013) or in reference to embodied forms of professional practice (Green, Thompson et al. 2002).

A small number of approaches attempt to theorise individuals' risk work amidst wider organisational pressures in a very specific sense. Bardach and Schoenberg's (2012) 'theory of triadic influence' associates intrapersonal and situational dynamics, connecting these, in turn, with wider social environmental processes. Nading's (2013) use of a 'medical citizenship brokerage' approach (drawing on Wolf 1956), meanwhile, encourages researchers to consider routine preventative encounters as "moments for observing the intersection of biomedicine, social justice and the making of state subjects" and the "moral economic contradictions" these precipitate (Nading 2013: 99). These perspectives are fleshed out further by many other articles which, after providing critical reviews of sensitising theories in the background section, could be termed as doing theory ' with a small $t$ ' - often employing a more grounded theory or applied approach - which draws our attention to the line drawing or boundary management role of those working with health risks (Williams, Alderson et al. 2002) and the wider cultural contexts which implicitly shape such risk work practices (CriccoLizza 2010, Roscigno, Savage et al. 2012).

Given these theoretical leanings, it is unsurprising that qualitative methodological approaches, such as participant-observation and in-depth interviewing, dominate the literature, although there was some variation with focus groups, surveys, and secondary analysis of quantitative data also undertaken. There was a great range in the extent to which the authors of the articles engaged in reflexivity about their normative positioning in relation to biomedical understandings of health risk. In some parts of the (more applied) literature less critical approaches were adopted (Maconachie and Lewendon 2004, Bean and Catania 2013). In other articles, however, a direct critical engagement with issues of moral discourse was found, such as Sarkadia et al.'s (2004) study of cervical screening which explored the different value systems at play in screening; Thomas' (2015) study of screening for Down's 
syndrome, which explored changing professional and societal views on disability; studies that explore working practices in complementary and alternative medicine (Broom and Adams 2009, Nissen 2013); those that argue that HCPs are in a position to challenge colonial relationships of power (Darroch and Giles 2015), and those that take a feminist perspective on issues such as menopause (Green, Thompson et al. 2002, Murtagh and Hepworth 2003).

\section{COMPONENTS OF RISK WORK}

We identified the following components of risk work within the literature: 1) translating risk into different contexts; 2) minimizing risks in practice, and; 3) caring in the context of risk. Within each, we include both description of the nature and characteristics of the work itself along with our critical analysis of the social context and the tensions and challenges that this work produces.

\section{Translating risk}

Translating risk information into different contexts for different audiences is central to risk work and was reported in nearly all reviewed articles. Probabilistic risk based on populationlevel data needs to be translated to the individual facing health risks, and individual risk needs to be converted into auditable data for the use of health organisations. The challenge within these translation processes is the desire for safety and certainty within an inherently uncertain situation. Translating probabilistic risk about health outcomes, derived from epidemiological studies, to the individual requires 'telling interpretative stories' (Tanenbaum 1994: 31), which is not a purely technical process, but one that requires the building of trust and understanding between the patient and healthcare practitioner (Wood, Prior et al. 2003, Gale, Greenfield et al. 2011). By translating 'up', risk work can involve the identification and recording of individual or local risks for audit of processing at organisational levels - assessing risk, making decisions, and accounting for those decisions (Horlick-Jones 2005) This process can be problematic however as it elides nuance of experience in the process of converting complex professional judgements into 'objective' numerical information (Iversen 2014).

The process of localisation or tailoring of abstract knowledge to its specific context or vice versa can therefore be seen as a key challenge of risk work. In the context of 'epistemological 
uncertainty' (Fox 2002), the worker must draw on other (non-probabilistic) forms of knowledge about risk in the translation process. A variety of terms have been used in the literature, such as 'tacit knowledge' (Wood, Prior et al. 2003, Scamell and Stewart 2014, MacLeod and Stadnyk 2015), 'broad, practical experiences' (Williams, Alderson et al. 2002), 'intuition' (Warner and Gabe 2004), intuitive expertise and embodied knowledge (Godin 2004). In some cases, these alternative knowledges were seen as complementary, whereas in others tacit and local knowledges were used to subvert, challenge or supersede technical, authorized or standardized knowledge (Ruston 2006, Wardlow 2012). Translating risk is a fundamentally social process and different methods of implementing interventions may have unintended consequences for who those access them. For instance, Hernandez (2013) compared uniform and tailored application of recommendations for supplements in pregnancy, finding that the former resulted in fewer social disparities in uptake.

\section{Minimizing risk}

Implementing strategies to minimise risks and maximise safety in the face of uncertainty was the second most prominent component of risk work explored in the literature. This involves activities such as encouraging or supporting behaviour changes in patient or service users, or the administration (or not) of medication and other healthcare interventions, or developing new policies or procedures. A couple of papers noted that there may also be a gap between the expectations that healthcare practitioners would do preventative work, and the resources available to them and their knowledge about how to do it (Orleans, George et al. 1985, Saïas, Véron et al. 2014). Crucially, however, other non-health-related risks were at play and so minimising risks in practice requires balancing health risks with other kinds of concerns (Broom, Broom et al. 2014, Davis, Flowers et al. 2014, Szott 2014). Mostly commonly, the balancing act required acknowledgement and negotiation regarding how health risks are understood via social and moral lines as well as through the medical evidence (Douglas 1992, Cricco-Lizza 2010, Cabral, Lucas et al. 2015). Some articles explored how professionals' own (negative) judgements, mediated by societal perceptions of issues such as obesity, mental illness or sexuality, had a mediating effect on their risk minimization efforts (Warner and Gabe 2004, Mishra and Graham 2012, Kirk, Price et al. 2014). 
The question of where the locus of responsibility lies for risk minimization work influences the nature and organisation of risk work. At one end of the spectrum, the worker may be an agent of the state responsible for risk minimization, potentially also conscious of the persistence of health inequalities and their structural roots. Certain health risks are more commonly held to be the responsibility of the state, such as some communicable diseases (Davis, Flowers et al. 2014). At the other end of the spectrum, the worker may be tasked with ensuring that individuals are held accountable for any negative impact of their 'behaviours' on their health, as may emerge within 'education' interventions (Mishra and Graham 2012, Darroch and Giles 2015). There are, within the literature, hints of a more critical health and social care practice within neo-liberal political systems; one that acknowledges the limitations of individualistic models of health risk (Murtagh and Hepworth 2003, Frohlich, Mykhalovskiy et al. 2012) and indeed some social-democratic systems, such as in Scandinavia, offer a stronger community and state driven perspective. Where the responsibility lies for risk is dependent, at least in part, on policy makers' and professionals' political views and interpretation of the evidence on social determinants of health (Delawarde, Saïas et al. 2014).

\section{Caring in the context of risk}

Caring for people facing uncertain health futures is a third component of risk work reported in the literature. Care can be in the form of supporting people to make choices, or preventing undue alarm after receiving risk information (Olin Lauritzen and Sachs 2001, Roscigno, Savage et al. 2012, Schwennesen and Koch 2012). Care can sometimes be hard to reconcile with other aspects of risk work - translations require accountability upwards, which may threaten trust within the practitioner-patient relationship (Brown and Calnan 2013) and risk minimization might challenge practitioners' commitments to enhancing patient choice or control (Hall, Tomkinson et al. 2012).

Caring in the context of risk produces a fundamental challenge in risk work between negotiating 'normality' and 'risk', and this is explored to some extent in the literature. The nature of probabilistic risk knowledge means that it is hard for healthcare practitioners to be definitive with their patients about what is a 'real' risk (Williams, Alderson et al. 2002) and what counts as a risk is dependent on social, political, and ethical constructions (Thomas 2015). There were reflections on the nature of the power relationship between patient and 
practitioner and, in particular, critical accounts of the retention of control by the practitioner (Zayts and Sarangi 2013, Arribas-Ayllon and Sarangi 2014). The power of risk workers, within the public health agenda, to define people as 'at risk' creates a new health-related identity (Timmermans and Buchbinder 2010). From a positive perspective, this 'at risk' status offers health workers the opportunity to intervene and reduce the chances of that event happening (Hindhede 2014), but others have argued that making people take up the sick role early can have a negative impact on health (as it is bound up with identity) rather than improving it (Kreiner and Hunt 2014).

\section{FUTURE RESEARCH DIRECTIONS}

\section{(A) Embodied identities and subjectivity in risk work}

Patient or lay subjectivity in relation to risk has been much more thoroughly explored in the sociological literature than the subjectivity of professionals or other healthcare workers. The creation of 'new' patient/service user identities was identified as a key outcome - whether explicitly intended or not - of the interactions with health workers (Frohlich, Mykhalovskiy et al. 2012, Nissen 2013, Hindhede 2014, Villaamil 2014). Some articles explored spaces where there was negotiation at play, such as when mid-life women are requesting HRT and stress the social risks and benefits, while professionals stress the health risks and benefits (Green, Thompson et al. 2002). Socio-economic diversity within the 'at risk' populations influenced the risk work, and some papers explored the complexities of intersection between gender, class, ethnicity, sexuality or other dimensions of identity (Murtagh and Hepworth 2003, Warner and Gabe 2004, Warner 2006, Frohlich, Mykhalovskiy et al. 2012, Mishra and Graham 2012, Wardlow 2012, Nissen 2013, Benoit, Stengel et al. 2014, Villaamil 2014, Darroch and Giles 2015).

However, there are many fewer studies that explore the ways that workers forge their own professional and personal identities. The challenges and tensions around each component of risk work need to be managed both at a personal and embodied level as well as in terms of professional identity and credibility. For instance, as a translator of risk, the health worker may perform, or literally embody, a mediating role between different groups or stakeholders 
(Warner 2006). As a minimizer of risk, we noted above that there may be tensions between delivering on risk minimization targets and wanting to support patient choice and control or building trust (Brown and Calnan 2013). A number of articles touched upon discontinuity between workers' personal behaviour and their professional views and behaviours, such as on vaccination or the use of statins (Maconachie and Lewendon 2004, Raude, Fischler et al. 2004, Gale, Greenfield et al. 2011). Practices could change over time when subsequent experiences (of both practitioners and patients) could alter workers' views on the safety and risks of treatments (Bean and Catania 2013, Cabral, Lucas et al. 2015). Probably the most developed account of worker subjectivity in the literature is Nading's (2013) ethnography of Nicaraguan community health workers managing Dengue fever, which showed these workers' attempts to be 'model-citizens' in terms of role modelling safe practices in their own homes, as well as being 'citizen witnesses' by representing the needs of their neighbours to the state. The tensions involved in risk work need to be managed at a personal/embodied level as well as in terms of professional identity and credibility, but this remains largely unexplored in the literature.

\section{(B) Comparative research}

A critical next step in the development of a theory of risk work would be comparative research - across nature of risk, types of worker, and health system/organisational structures. Comparisons across types of risk work would enable investigation of the extent to which risk work was affected by issues such as the certainty of the knowledge base of risk, the type of health risk in question (e.g. mental, physical, maternal), where on the spectrum such 'risk' is located - from early detection of disease to general promotion of wellbeing - and its relationship with other risks (such as social, moral or organisational). This may help to understand whether the rise of risk work is resulting in a reconfiguration of existing professions through the co-option of new domains of practice, or whether it is producing a new group of healthcare workers to meet new understandings of need.

Comparisons of risk work across different professional, para-professional or lay worker groups would enable a greater understanding of skills and knowledge required to undertake translation, minimization and care in the context of risk. Although differences have been observed in relation to different professions (Broom and Adams 2009), the extent to which 
the status and training of professionals affects practices remains unclear within the literature. Additionally, practice within different health spaces (private, community, primary, secondary care) and organisational contexts is relevant. The need for translating raises important sociological questions about the environments, institutions or organisations across which the translating is taking place. While the general trend for organisations to be driven by risk management has been noted, along with comments on the ways in which organisations seek to sustain their credibility in the face of uncertainty (Davis, Flowers et al. 2014), the implications for everyday work have been less explored (Scamell and Alaszewski 2012). Exploration of the micro-landscapes of the working environments in which risk work takes places, such as working conditions and the architectures, materiality and organisation of 'health' spaces would aid this analysis. The development of identity and subjective positioning and intentionality may vary depending on professional status and other markers of identity, such as gender or ethnicity. There remains a great deal of scope within the literature for further exploration of how the personal/professional identity nexus of the risk worker is mediated by other factors, such as status of the worker, working conditions, types of risk involved, type of client, and the moral dimension implicit in the work.

The use of international comparisons would help to explicate how risk work is shaped by wider social, economic, political and cultural structures and systems. For instance, this work may be happening amidst pressures towards cost-saving and/or decentralisation of healthcare services. Comparisons could centre on the cultures of different health and welfare regimes; the extent to which risk and prevention is a way in which these regimes build legitimacy; whether they seek to transfer risk to the individual/private realm; the extent to which health risks are engaged with through private, state or Third Sector providers, and the ways in which different systems mediate or shape the power of the medical and pharmaceutical industries. Finally, micro-sociological comparison could explore the impact of interpersonal cultures in different organisations or countries, not least with regard to how risk work 'gets done' (Horlick-Jones 2005).

\section{(C) Theoretical and methodological diversity}

It may be that future research would benefit from using a greater range of methodological and theoretical approaches, including critical sociological approaches. There are fewer 
studies that ask 'what is the risk work doing' within a wider sociological framework - for instance in terms of potentially privatizing risk, accumulating profit, or legitimizing the power of the state or the medical profession. There are currently fewer quantitative studies that map the macro-economic and political landscapes of risk work and its scale. There are also fewer close micro-social accounts of the production of 'risk' through everyday working practices, that might be achieved through use of participant-observation or conversation analysis to explore what is said, and not said, in these interactions (Iversen 2014). Risk is inherently 'virtual' (van Loon 2014) and it is partly through risk work that risk is made socially and politically compelling to those 'at risk' . Finally, the large number of interview studies that we reviewed often tended to focus on the patient or the interaction. There were only hints of the experiential, interpretative, embodied aspects of risk work, including questions about identity and relational proximity to the 'at risk' community.

\section{CONCLUSION}

In summary, we have argued that the concept of risk work, drawing on the sociologies of risk and of work, has salience to the fields of health and healthcare. We have identified the key components of risk work reported in the literature: translating risk into different contexts, minimizing risks in practice, and caring in the context of risk. We have suggested that there is scope for future exploration of ways in which risk workers forge their own professional and personal identity. We have discussed the practical and conceptual tensions in risk work and argued that comparative research would illuminate the varying ways in which those tensions are managed. Finally, we have argued that more diversity in methodological approaches would greatly enhance this emerging field of study 
Table 1: Summary of included papers (alphabetical)

\begin{tabular}{|c|c|c|c|c|c|c|c|}
\hline $\begin{array}{l}\text { Author } \\
\text { (Date) }\end{array}$ & Article title & $\begin{array}{l}\text { Occupation/profession of } \\
\text { worker }\end{array}$ & $\begin{array}{l}\text { Type of health } \\
\text { risk }\end{array}$ & Setting & Methods & Theory & $\begin{array}{l}\text { Aspects of } \\
\text { risk work }\end{array}$ \\
\hline $\begin{array}{l}\text { Arribas- } \\
\text { Ayllon and } \\
\text { Sarangi } \\
\text { (2014) }\end{array}$ & $\begin{array}{l}\text { Counselling uncertainty: } \\
\text { genetics professionals' } \\
\text { accounts of } \\
\text { (non)directiveness and } \\
\text { trust/distrust }\end{array}$ & $\begin{array}{l}\text { Paediatric } \\
\text { and genetic services } \\
\text { professionals }\end{array}$ & $\begin{array}{l}\text { Risk of child being } \\
\text { diagnosed as } \\
\text { having a genetic } \\
\text { disorder. }\end{array}$ & UK & Interviews & $\begin{array}{l}\text { No explicit framework } \\
\text { used, but sensitising } \\
\text { theory provided on } \\
\text { uncertainty, trust, and } \\
\text { non-directiveness. }\end{array}$ & $\begin{array}{l}\text { Translating, } \\
\text { caring }\end{array}$ \\
\hline $\begin{array}{l}\text { Bardach \& } \\
\text { Schoenberg } \\
(2012)\end{array}$ & $\begin{array}{l}\text { Primary Care Physicians' } \\
\text { Prevention } \\
\text { Counselling With Patients } \\
\text { With Multiple Morbidity }\end{array}$ & Primary care physicians & $\begin{array}{l}\text { Complications } \\
\text { from multiple } \\
\text { morbidity }\end{array}$ & USA & $\begin{array}{l}\text { In-depth, } \\
\text { semi- } \\
\text { structured } \\
\text { interviews }\end{array}$ & $\begin{array}{l}\text { Theory of Triadic } \\
\text { Influence on } \\
\text { health behaviours. }\end{array}$ & $\begin{array}{l}\text { Translating, } \\
\text { minimizing }\end{array}$ \\
\hline $\begin{array}{l}\text { Bean \& } \\
\text { Catania } \\
(2013)\end{array}$ & $\begin{array}{l}\text { Vaccine Perceptions Among } \\
\text { Oregon Health Care } \\
\text { Providers }\end{array}$ & $\begin{array}{l}\text { Orthodox healthcare } \\
\text { providers (allopathic or } \\
\text { osteopathic physicians, } \\
\text { paediatricians and nurses) } \\
\text { and complementary and } \\
\text { alternative providers } \\
\text { (chiropractors and } \\
\text { midwives). }\end{array}$ & $\begin{array}{l}\text { Risk of } \\
\text { nonvaccination } \\
\text { and subsequent } \\
\text { public health risk }\end{array}$ & USA & $\begin{array}{l}\text { Semi- } \\
\text { structured } \\
\text { interviews }\end{array}$ & Health Belief Model & Minimizing \\
\hline $\begin{array}{l}\text { Benoit et al. } \\
(2014)\end{array}$ & $\begin{array}{l}\text { Providers' constructions of } \\
\text { pregnant and early } \\
\text { parenting women who use } \\
\text { substances }\end{array}$ & $\begin{array}{l}\text { Health and social care } \\
\text { professionals who provide } \\
\text { services to pregnant } \\
\text { women who use } \\
\text { substances. }\end{array}$ & $\begin{array}{l}\text { Risk to the baby's } \\
\text { health of } \\
\text { substance-use by } \\
\text { mother, and } \\
\text { secondarily, the } \\
\text { mother's health }\end{array}$ & Canada & $\begin{array}{l}\text { Semi- } \\
\text { structured } \\
\text { interviews }\end{array}$ & $\begin{array}{l}\text { No explicit framework } \\
\text { specified. However, the } \\
\text { focus on the gendered } \\
\text { aspects of the participants' } \\
\text { stories suggests feminist } \\
\text { influences. }\end{array}$ & Caring \\
\hline $\begin{array}{l}\text { Broom \& } \\
\text { Adams } \\
(2009)\end{array}$ & $\begin{array}{l}\text { Oncology clinicians' } \\
\text { accounts of discussing } \\
\text { complementary and } \\
\text { alternative medicine with } \\
\text { their patients }\end{array}$ & $\begin{array}{l}\text { Oncology consultants and } \\
\text { nurses }\end{array}$ & $\begin{array}{l}\text { Risk of using } \\
\text { complementary } \\
\text { and alternative } \\
\text { medicine (CAM) } \\
\text { alongside } \\
\text { orthodox } \\
\text { treatment for } \\
\text { cancer }\end{array}$ & Australia & Interviews & $\begin{array}{l}\text { No explicit framework } \\
\text { used, but sensitising } \\
\text { theory provided on use of } \\
\text { Complementary and } \\
\text { Alternative Medicine. }\end{array}$ & $\begin{array}{l}\text { Translating, } \\
\text { minimizing, } \\
\text { caring }\end{array}$ \\
\hline
\end{tabular}




\begin{tabular}{|c|c|c|c|c|c|c|c|}
\hline $\begin{array}{l}\text { Broom \& } \\
\text { Doron (2013) }\end{array}$ & $\begin{array}{l}\text { Traditional Medicines, } \\
\text { Collective Negotiation, and } \\
\text { Representations of Risk in } \\
\text { Indian Cancer Care }\end{array}$ & $\begin{array}{l}\text { Medical specialists (medical } \\
\text { oncologists, radiation } \\
\text { oncologists, } \\
\text { palliative care specialists, } \\
\text { surgeons, haematological } \\
\text { oncologists, paediatric } \\
\text { haematologists), oncology } \\
\text { nurses, } \\
\text { and oncology clinical } \\
\text { psychologist. }\end{array}$ & $\begin{array}{l}\text { Risks associated } \\
\text { with using } \\
\text { traditional, } \\
\text { complementary } \\
\text { and alternative } \\
\text { medicines (TCAM) } \\
\text { and biomedical } \\
\text { medicines } \\
\text { together without } \\
\text { discussions with } \\
\text { clinician }\end{array}$ & India & $\begin{array}{l}\text { In-depth } \\
\text { interviews }\end{array}$ & $\begin{array}{l}\text { No explicit framework } \\
\text { used, but sensitising } \\
\text { theory provided on cancer, } \\
\text { communication, TCAM, the } \\
\text { Indian clinical context, } \\
\text { familial power in India, and } \\
\text { collectivism versus } \\
\text { individualism in India. }\end{array}$ & $\begin{array}{l}\text { Translating, } \\
\text { minimizing }\end{array}$ \\
\hline $\begin{array}{l}\text { Broom et } \\
\text { al.(2014) }\end{array}$ & $\begin{array}{l}\text { Cultures of resistance? A } \\
\text { Bourdieusian analysis of } \\
\text { doctors' antibiotic } \\
\text { prescribing }\end{array}$ & Hospital-based doctors & $\begin{array}{l}\text { Risk of } \\
\text { inappropriately } \\
\text { prescribing } \\
\text { antibiotics and } \\
\text { contributing to } \\
\text { antimicrobial } \\
\text { resistance. }\end{array}$ & Australia & Interviews & $\begin{array}{l}\text { Bourdieu's theory of } \\
\text { practice and the habitus of } \\
\text { the social world of the } \\
\text { hospital. }\end{array}$ & $\begin{array}{l}\text { Minimizing, } \\
\text { caring }\end{array}$ \\
\hline $\begin{array}{l}\text { Brown \& } \\
\text { Calnan } \\
(2013)\end{array}$ & $\begin{array}{l}\text { Trust as a Means of Bridging } \\
\text { the Management of Risk } \\
\text { and the Meeting of Need: A } \\
\text { Case Study in Mental Health } \\
\text { Service Provision }\end{array}$ & $\begin{array}{l}\text { Mental health professionals } \\
\text { and } \\
\text { managers }\end{array}$ & $\begin{array}{l}\text { Risk of not } \\
\text { meeting patients' } \\
\text { mental health } \\
\text { needs; perceived } \\
\text { risks patients } \\
\text { pose to the public }\end{array}$ & UK & Interviews & $\begin{array}{l}\text { Framed in terms of 'risk } \\
\text { society' (Beck 1992), } \\
\text { tensions between ideas of } \\
\text { risk and need in mental } \\
\text { health, and the potential } \\
\text { role of trust in mediating } \\
\text { these. }\end{array}$ & $\begin{array}{l}\text { Translating, } \\
\text { minimizing, } \\
\text { caring }\end{array}$ \\
\hline $\begin{array}{l}\text { Burton- } \\
\text { Jeangros et } \\
\text { al. (2013) }\end{array}$ & $\begin{array}{l}\text { Between tolerable } \\
\text { uncertainty and } \\
\text { unacceptable risks: how } \\
\text { health professionals and } \\
\text { pregnant women think } \\
\text { about the probabilities } \\
\text { generated by prenatal } \\
\text { screening }\end{array}$ & Gynaecologists & $\begin{array}{l}\text { Foetal } \\
\text { abnormalities: } \\
\text { prenatal } \\
\text { screening is being } \\
\text { used to try to } \\
\text { reduce these. }\end{array}$ & Switzerland & $\begin{array}{l}\text { Semi-focused } \\
\text { interviews }\end{array}$ & $\begin{array}{l}\text { No explicit framework } \\
\text { used, but sensitising } \\
\text { theory provided around } \\
\text { risk, uncertainty, } \\
\text { surveillance and modes of } \\
\text { probablistic thinking. }\end{array}$ & $\begin{array}{l}\text { Translating, } \\
\text { minimizing, } \\
\text { caring }\end{array}$ \\
\hline
\end{tabular}




\begin{tabular}{|c|c|c|c|c|c|c|c|}
\hline $\begin{array}{l}\text { Cabral et al. } \\
(2015)\end{array}$ & $\begin{array}{l}\text { "It's safer to ..." parent } \\
\text { consulting and clinician } \\
\text { antibiotic prescribing } \\
\text { decisions for children with } \\
\text { respiratory tract infections: } \\
\text { An analysis across four } \\
\text { qualitative studies }\end{array}$ & Primary care clinicians & $\begin{array}{l}\text { Respiratory tract } \\
\text { infections and use } \\
\text { of antibiotics }\end{array}$ & Australia & $\begin{array}{l}\text { Focus groups; } \\
\text { interviews; } \\
\text { qualitative } \\
\text { systematic } \\
\text { review }\end{array}$ & $\begin{array}{l}\text { Social construction of } \\
\text { vulnerability of children } \\
\text { and its influences on } \\
\text { prescribing behaviour }\end{array}$ & $\begin{array}{l}\text { Translating, } \\
\text { minimizing, } \\
\text { caring }\end{array}$ \\
\hline $\begin{array}{l}\text { Cricco-Lizza } \\
(2010)\end{array}$ & $\begin{array}{l}\text { Everyday Nursing Practice } \\
\text { Values in the NICU and } \\
\text { Their Reflection on } \\
\text { Breastfeeding Promotion }\end{array}$ & $\begin{array}{l}\text { Neonatal intensive care } \\
\text { unit nurses }\end{array}$ & $\begin{array}{l}\text { Risk of babies' } \\
\text { 'potential' not } \\
\text { being } \\
\text { 'maximised': } \\
\text { babies not } \\
\text { thriving and doing } \\
\text { as well, lifelong, } \\
\text { as they could if } \\
\text { they were } \\
\text { breastfed. }\end{array}$ & USA & Ethnography & $\begin{array}{l}\text { No explicit framework } \\
\text { used, but sensitising } \\
\text { theory provided on culture } \\
\text { and values in professional } \\
\text { practice }\end{array}$ & $\begin{array}{l}\text { Translating, } \\
\text { minimizing }\end{array}$ \\
\hline $\begin{array}{l}\text { Darroch \& } \\
\text { Giles (2015) }\end{array}$ & $\begin{array}{l}\text { Health/Service Providers' } \\
\text { Perspectives on Barriers to } \\
\text { Healthy Weight Gain and } \\
\text { Physical Activity in } \\
\text { Pregnant, Urban First } \\
\text { Nations Women }\end{array}$ & $\begin{array}{l}\text { Midwife, program } \\
\text { directors, dietitian, nurse } \\
\text { practitioner, social workers, } \\
\text { yoga instructor/community } \\
\text { facilitator, personal } \\
\text { trainers, cultural educator, } \\
\text { prenatal program } \\
\text { employee, } \\
\text { familycoordinator for early } \\
\text { childhood program, } \\
\text { community fitness leader, } \\
\text { and physical activity } \\
\text { programmingassistant. }\end{array}$ & $\begin{array}{l}\text { Risks posed to } \\
\text { pregnant women } \\
\text { and their unborn } \\
\text { children if they } \\
\text { gain unhealthy } \\
\text { amounts of } \\
\text { weight in } \\
\text { pregnancy and } \\
\text { take little } \\
\text { exercise. }\end{array}$ & Canada & $\begin{array}{l}\text { Semi- } \\
\text { structured } \\
\text { interviews }\end{array}$ & $\begin{array}{l}\text { Constructionist approach, } \\
\text { with a postcolonial } \\
\text { feminist lens. }\end{array}$ & $\begin{array}{l}\text { Translating, } \\
\text { minimizing }\end{array}$ \\
\hline
\end{tabular}


Article accepted for publication in Sociology Compass 01/08/2016

\begin{tabular}{|c|c|c|c|c|c|c|c|}
\hline $\begin{array}{l}\text { Davis et al. } \\
\text { (2014) }\end{array}$ & $\begin{array}{l}\text { 'We had to do what we } \\
\text { thought was right at the } \\
\text { time': retrospective } \\
\text { discourse on the } 2009 \text { H1N1 } \\
\text { pandemic in the UK }\end{array}$ & $\begin{array}{l}\text { Public health practitioners: } \\
\text { health physicians, } \\
\text { epidemiologists, virologists, } \\
\text { biomedical scientists and } \\
\text { public health officers. }\end{array}$ & $\begin{array}{l}\text { Risk of a flu } \\
\text { pandemic (H1N1) } \\
\text { spreading further. }\end{array}$ & UK & $\begin{array}{l}\text { Interview } \\
\text { (either face-to- } \\
\text { face or via } \\
\text { email) }\end{array}$ & $\begin{array}{l}\text { Foucauldian-oriented } \\
\text { critical discourse analysis. } \\
\text { Exploring the perspective } \\
\text { that uncertainty requires } \\
\text { attempts to sustain expert } \\
\text { authority in the face of } \\
\text { uncertainty. }\end{array}$ & $\begin{array}{l}\text { Translating, } \\
\text { minimizing }\end{array}$ \\
\hline $\begin{array}{l}\text { Delawarde et } \\
\text { al. (2014) }\end{array}$ & $\begin{array}{l}\text { The public health dogma of } \\
\text { evidence-based mental } \\
\text { disorders prevention and } \\
\text { mental health promotion: } \\
\text { French professionals' } \\
\text { beliefs in regard to } \\
\text { parenting programs }\end{array}$ & $\begin{array}{l}\text { Professionals working } \\
\text { within a mental } \\
\text { health prevention and } \\
\text { promotion framework. }\end{array}$ & Mental disorders & France & $\begin{array}{l}\text { Grounded } \\
\text { theory: } \\
\text { ethnographic } \\
\text { methods and } \\
\text { semi- } \\
\text { structured } \\
\text { interviews }\end{array}$ & $\begin{array}{l}\text { Abbott's (1988) theory of } \\
\text { professional jurisdiction }\end{array}$ & Minimizing \\
\hline $\begin{array}{l}\text { Frohlich et al. } \\
\text { (2012) }\end{array}$ & $\begin{array}{l}\text { Creating the socially } \\
\text { marginalised youth smoker: } \\
\text { the role of tobacco control }\end{array}$ & $\begin{array}{l}\text { Tobacco control } \\
\text { practitioners }\end{array}$ & $\begin{array}{l}\text { Risk of young } \\
\text { people taking up } \\
\text { smoking and } \\
\text { causing damage } \\
\text { to current and } \\
\text { future health. }\end{array}$ & Canada & $\begin{array}{l}\text { Semi- } \\
\text { structured } \\
\text { interviews }\end{array}$ & $\begin{array}{l}\text { Framed by Foucauldian } \\
\text { theories of } \\
\text { governmentality, extended } \\
\text { to explore intersections } \\
\text { with the social relations of } \\
\text { class. }\end{array}$ & $\begin{array}{l}\text { Translating, } \\
\text { minimizing }\end{array}$ \\
\hline Godin (2004) & $\begin{array}{l}\text { 'You don't tick boxes on a } \\
\text { form': A study of how } \\
\text { community mental health } \\
\text { nurses assess and manage } \\
\text { risk }\end{array}$ & $\begin{array}{l}\text { Community mental health } \\
\text { nurses }\end{array}$ & $\begin{array}{l}\text { Harm to others } \\
\text { and self }\end{array}$ & UK & Interviews & $\begin{array}{l}\text { No explicit framework } \\
\text { used, but sensitising } \\
\text { theory provided on the } \\
\text { culture of mental health } \\
\text { care, such as Castel's } \\
\text { concept of the } \\
\text { epidemiological clinic. }\end{array}$ & $\begin{array}{l}\text { Translating, } \\
\text { minimizing, } \\
\text { caring }\end{array}$ \\
\hline
\end{tabular}


Article accepted for publication in Sociology Compass 01/08/2016

\begin{tabular}{|c|c|c|c|c|c|c|c|}
\hline $\begin{array}{l}\text { Green et al. } \\
(2002)\end{array}$ & $\begin{array}{l}\text { Narratives of risk: Women } \\
\text { at midlife, medical 'experts' } \\
\text { and health technologies }\end{array}$ & $\begin{array}{l}\text { Health professionals } \\
\text { working in GP practices, } \\
\text { specialist and community } \\
\text { clinics }\end{array}$ & $\begin{array}{l}\text { Menopausal } \\
\text { health risks (use } \\
\text { of hormone } \\
\text { replacement } \\
\text { therapy, } \\
\text { osteoporosis, } \\
\text { breast cancer) }\end{array}$ & UK & $\begin{array}{l}\text { Semi- } \\
\text { structured } \\
\text { interviews, } \\
\text { recordings of } \\
\text { clinical } \\
\text { consultations; } \\
\text { focus groups } \\
\text { with } \\
\text { stakeholders }\end{array}$ & $\begin{array}{l}\text { No explicit framework } \\
\text { used, but sensitising } \\
\text { theory provided regarding } \\
\text { feminist perspectives on } \\
\text { the menopause; } \\
\text { sociological accounts of } \\
\text { the body and } \\
\text { embodiment; Giddens and } \\
\text { Beck on risk, and Foucault } \\
\text { on surveillance. }\end{array}$ & $\begin{array}{l}\text { Translating, } \\
\text { minimizing, } \\
\text { caring }\end{array}$ \\
\hline $\begin{array}{l}\text { Griffiths et al. } \\
(2006)\end{array}$ & $\begin{array}{l}\text { Health professionals, their } \\
\text { medical interventions and } \\
\text { uncertainty: A study } \\
\text { focusing on women at } \\
\text { midlife }\end{array}$ & $\begin{array}{l}\text { Nurses, doctors and } \\
\text { radiographers from NHS } \\
\text { health care sites (a breast } \\
\text { screening and follow up } \\
\text { clinic, a bone } \\
\text { clinic including bone } \\
\text { densitometry and an HRT } \\
\text { clinic) }\end{array}$ & $\begin{array}{l}\text { Breast screening, } \\
\text { hormone } \\
\text { replacement } \\
\text { therapy and } \\
\text { bone } \\
\text { densitometry }\end{array}$ & UK & $\begin{array}{l}\text { Semi- } \\
\text { structured } \\
\text { interviews }\end{array}$ & $\begin{array}{l}\text { Fox's concept of medical } \\
\text { uncertainty }\end{array}$ & $\begin{array}{l}\text { Translating, } \\
\text { minimizing }\end{array}$ \\
\hline $\begin{array}{l}\text { Hall et al. } \\
\text { (2012) }\end{array}$ & $\begin{array}{l}\text { Canadian Care Providers' } \\
\text { and Pregnant Women's } \\
\text { Approaches to Managing } \\
\text { Birth: Minimizing Risk While } \\
\text { Maximizing Integrity }\end{array}$ & $\begin{array}{l}\text { Nurses, physicians, } \\
\text { midwives, and } \\
\text { doulas }\end{array}$ & $\begin{array}{l}\text { Risks posed to } \\
\text { woman and baby } \\
\text { during birth: how } \\
\text { best to manage } \\
\text { these from } \\
\text { different clinical } \\
\text { (and patient) } \\
\text { perspectives. }\end{array}$ & Canada & $\begin{array}{l}\text { Questionnaires } \\
\text { and focus } \\
\text { groups }\end{array}$ & Symbolic interactionism. & $\begin{array}{l}\text { Translating, } \\
\text { minimizing, } \\
\text { caring }\end{array}$ \\
\hline $\begin{array}{l}\text { Hernandez } \\
(2013)\end{array}$ & $\begin{array}{l}\text { Provider and patient } \\
\text { influences on the formation } \\
\text { of socioeconomic health } \\
\text { behavior disparities among } \\
\text { pregnant women }\end{array}$ & $\begin{array}{l}\text { Physicians, midwives, and } \\
\text { nurses involved in the care } \\
\text { of pregnant women }\end{array}$ & $\begin{array}{l}\text { Risk of not taking } \\
\text { Vitamin D or } \\
\text { Omega oil } \\
\text { supplements in } \\
\text { pregnancy }\end{array}$ & USA & $\begin{array}{l}\text { In-depth } \\
\text { interviews }\end{array}$ & $\begin{array}{l}\text { No explicit framework } \\
\text { used. }\end{array}$ & $\begin{array}{l}\text { Translating, } \\
\text { minimizing }\end{array}$ \\
\hline $\begin{array}{l}\text { Herron et al. } \\
(2001)\end{array}$ & $\begin{array}{l}\text { Attitudes Toward Suicide } \\
\text { Prevention in Front-Line } \\
\text { Health Staff }\end{array}$ & $\begin{array}{l}\text { General practitioners, } \\
\text { community psychiatric } \\
\text { nurses, accident and } \\
\text { emergency nursing staff, } \\
\text { psychiatrists. }\end{array}$ & $\begin{array}{l}\text { Suicide } \\
\text { prevention; } \\
\text { assessment and } \\
\text { management of } \\
\text { risk }\end{array}$ & UK & Survey & $\begin{array}{l}\text { No explicit framework } \\
\text { used. }\end{array}$ & $\begin{array}{l}\text { [Focus on } \\
\text { practitioner } \\
\text { beliefs] }\end{array}$ \\
\hline
\end{tabular}


Article accepted for publication in Sociology Compass 01/08/2016

\begin{tabular}{|c|c|c|c|c|c|c|c|}
\hline $\begin{array}{l}\text { Hindhede } \\
(2014)\end{array}$ & $\begin{array}{l}\text { Pre-diabetic categorisation: } \\
\text { the making of a new person }\end{array}$ & GPs and practice nurses & Diabetes & Denmark & $\begin{array}{l}\text { In-depth } \\
\text { interviews; } \\
\text { focus groups }\end{array}$ & $\begin{array}{l}\text { Bourdieu's theory of } \\
\text { practice and concept of } \\
\text { habitus }\end{array}$ & $\begin{array}{l}\text { Translating, } \\
\text { minimizing, } \\
\text { caring }\end{array}$ \\
\hline $\begin{array}{l}\text { Iversen } \\
(2014)\end{array}$ & $\begin{array}{l}\text { Recordability: Resistance } \\
\text { and collusion in } \\
\text { psychometric interviews } \\
\text { with children }\end{array}$ & Child welfare workers & $\begin{array}{l}\text { Violence in the } \\
\text { home }\end{array}$ & Sweden & $\begin{array}{l}\text { Conversation } \\
\text { analysis }\end{array}$ & Interactional psychology & $\begin{array}{l}\text { Translating, } \\
\text { caring }\end{array}$ \\
\hline $\begin{array}{l}\text { Kirk et al. } \\
(2014)\end{array}$ & $\begin{array}{l}\text { Blame, Shame, and Lack of } \\
\text { Support: A Multilevel Study } \\
\text { on Obesity Management }\end{array}$ & $\begin{array}{l}\text { Dieticians, family } \\
\text { physicians, nurses }\end{array}$ & Obesity & Canada & Interviews & $\begin{array}{l}\text { Feminist post- } \\
\text { structuralism (Foucault, } \\
\text { Butler) - questioning } \\
\text { everyday practices }\end{array}$ & $\begin{array}{l}\text { Translating, } \\
\text { minimizing, } \\
\text { caring }\end{array}$ \\
\hline $\begin{array}{l}\text { Kreiner \& } \\
\text { Hunt (2014) }\end{array}$ & $\begin{array}{l}\text { The pursuit of preventive } \\
\text { care for chronic illness: } \\
\text { turning healthy people into } \\
\text { chronic patients }\end{array}$ & $\begin{array}{l}\text { Clinicians in primary care } \\
\text { clinics }\end{array}$ & $\begin{array}{l}\text { Risk of getting a } \\
\text { chronic disease; } \\
\text { being an 'at risk' } \\
\text { patient. }\end{array}$ & USA & $\begin{array}{l}\text { Ethnography } \\
\text { (observations } \\
\text { of clinical } \\
\text { consultations, } \\
\text { and open- } \\
\text { ended } \\
\text { interviews) }\end{array}$ & $\begin{array}{l}\text { No explicit framework } \\
\text { used, but sensitising } \\
\text { theory provided on } \\
\text { prevention, disease, } \\
\text { population norms, clinical } \\
\text { guidelines, and risk. }\end{array}$ & $\begin{array}{l}\text { Translating, } \\
\text { minimizing, } \\
\text { caring }\end{array}$ \\
\hline $\begin{array}{l}\text { Lankshear et } \\
\text { al. (2005) }\end{array}$ & $\begin{array}{l}\text { Decision-making, } \\
\text { uncertainty and risk: } \\
\text { Exploring } \\
\text { the complexity of work } \\
\text { processes in NHS delivery } \\
\text { suites }\end{array}$ & $\begin{array}{l}\text { Consultants, registrars, } \\
\text { staff grades, } \\
\text { midwives, trainee } \\
\text { midwives, nursing } \\
\text { auxiliaries, managers, } \\
\text { anaesthetists }\end{array}$ & $\begin{array}{l}\text { Risk of labour } \\
\text { being abnormal } \\
\text { and causing baby } \\
\text { or woman } \\
\text { harm/possible } \\
\text { death }\end{array}$ & UK & Ethnography & $\begin{array}{l}\text { No explicit framework } \\
\text { used, but sensitising } \\
\text { theory provided on risk } \\
\text { society, defensive } \\
\text { medicine and clinical } \\
\text { decision making. }\end{array}$ & $\begin{array}{l}\text { Translating, } \\
\text { minimizing, } \\
\text { caring }\end{array}$ \\
\hline $\begin{array}{l}\text { MacLeod \& } \\
\text { Stadnyk } \\
(2015)\end{array}$ & $\begin{array}{l}\text { Risk: 'I know it when I see } \\
\text { it': how health and social } \\
\text { practitioners defined and } \\
\text { evaluated living at risk } \\
\text { among community-dwelling } \\
\text { older adults }\end{array}$ & $\begin{array}{l}\text { Community practitioners } \\
\text { involved } \\
\text { in in-home services for } \\
\text { older adults }\end{array}$ & $\begin{array}{l}\text { Individual health } \\
\text { and safety risks of } \\
\text { older people }\end{array}$ & Canada & $\begin{array}{l}\text { Grounded } \\
\text { theory: semi- } \\
\text { structured } \\
\text { interviews, }\end{array}$ & $\begin{array}{l}\text { No theoretical framework } \\
\text { as using grounded theory, } \\
\text { but sensitising theory } \\
\text { provided around concept } \\
\text { of risk. }\end{array}$ & Translating \\
\hline $\begin{array}{l}\text { Maconachie } \\
\text { \& Lewendon } \\
(2004)\end{array}$ & $\begin{array}{l}\text { Immunising children in } \\
\text { Primary Care in the UK - } \\
\text { What are the concerns of } \\
\text { principal immunisers? }\end{array}$ & $\begin{array}{l}\text { Principal immunisers in } \\
\text { general practices: practice } \\
\text { nurses, general } \\
\text { practitioners, health } \\
\text { visitors. }\end{array}$ & $\begin{array}{l}\text { Risks of having } \\
\text { and not having } \\
\text { immunisations }\end{array}$ & UK & Survey (postal) & $\begin{array}{l}\text { No explicit framework } \\
\text { used. }\end{array}$ & $\begin{array}{l}\text { [Focus on } \\
\text { practitioner } \\
\text { beliefs] }\end{array}$ \\
\hline
\end{tabular}




\begin{tabular}{|c|c|c|c|c|c|c|c|}
\hline $\begin{array}{l}\text { Mishra \& } \\
\text { Graham } \\
(2012)\end{array}$ & $\begin{array}{l}\text { Risk, choice and the 'girl } \\
\text { vaccine': Unpacking human } \\
\text { papillomavirus (HPV) } \\
\text { immunisation }\end{array}$ & $\begin{array}{l}\text { Vaccine scientists and } \\
\text { public health } \\
\text { nurses }\end{array}$ & $\begin{array}{l}\text { HPV vaccine (in } \\
\text { terms of risks of } \\
\text { having it/ not } \\
\text { having it, for } \\
\text { individuals/ the } \\
\text { collective) }\end{array}$ & Canada & $\begin{array}{l}\text { Semi- } \\
\text { structured, in- } \\
\text { depth } \\
\text { interviews }\end{array}$ & $\begin{array}{l}\text { Foucault's theories of } \\
\text { governmentality and } \\
\text { technologies of the self, } \\
\text { with added gendered lens. }\end{array}$ & $\begin{array}{l}\text { Translating, } \\
\text { minimizing }\end{array}$ \\
\hline $\begin{array}{l}\text { Murtagh \& } \\
\text { Hepworth } \\
(2003)\end{array}$ & $\begin{array}{l}\text { Menopause as a long-term } \\
\text { risk to health: implications } \\
\text { of general practitioner } \\
\text { accountsof prevention for } \\
\text { women's choice and } \\
\text { decision-making }\end{array}$ & General practitioners & Menopause & Australia & $\begin{array}{l}\text { Semi- } \\
\text { structured } \\
\text { interviews }\end{array}$ & $\begin{array}{l}\text { Feminist challenges to the } \\
\text { medical model of } \\
\text { menopause used to frame } \\
\text { the study and the research } \\
\text { aims to examine } \\
\text { constructions of } \\
\text { menopause as they occur } \\
\text { within the context of } \\
\text { general medical practice. }\end{array}$ & $\begin{array}{l}\text { Translating, } \\
\text { minimizing }\end{array}$ \\
\hline $\begin{array}{l}\text { Nading } \\
\text { (2013) }\end{array}$ & $\begin{array}{l}\text { "Love isn't there in your } \\
\text { Stomach": a moral } \\
\text { economy of medical } \\
\text { citizenship among } \\
\text { Nicaraguan Community } \\
\text { Health Workers }\end{array}$ & Community health workers & Dengue fever & Nicaragua & $\begin{array}{l}\text { Participant- } \\
\text { observation }\end{array}$ & $\begin{array}{l}\text { Medical citizenship and } \\
\text { brokership (Wolf 1956). } \\
\text { Routine preventative } \\
\text { encounters seen as } \\
\text { "moments for observing } \\
\text { the intersection of } \\
\text { biomedicine, social justice } \\
\text { and the making of state } \\
\text { subjects". }\end{array}$ & $\begin{array}{l}\text { Translating, } \\
\text { minimizing, } \\
\text { caring }\end{array}$ \\
\hline Nissen (2013) & $\begin{array}{l}\text { Women's Bodies and } \\
\text { Women's Lives in Western } \\
\text { Herbal Medicine in the UK }\end{array}$ & Herbalists & $\begin{array}{l}\text { General health } \\
\text { promotion }\end{array}$ & UK & Ethnography & $\begin{array}{l}\text { No explicit framework } \\
\text { used, but sensitising } \\
\text { theory provided on } \\
\text { embodiment, technologies } \\
\text { of the self, and feminist } \\
\text { theories of gender. }\end{array}$ & $\begin{array}{l}\text { Translating, } \\
\text { minimizing, } \\
\text { caring }\end{array}$ \\
\hline $\begin{array}{l}\text { Olin } \\
\text { Lauritzen \& } \\
\text { Sachs (2001) }\end{array}$ & $\begin{array}{l}\text { Normality, risk and the } \\
\text { future: implicit } \\
\text { communication of threat in } \\
\text { health surveillance }\end{array}$ & $\begin{array}{l}\text { Health visitors, primary } \\
\text { health care nurses }\end{array}$ & $\begin{array}{l}\text { Communication } \\
\text { of risk language to } \\
\text { clients by health } \\
\text { care professionals }\end{array}$ & Sweden & $\begin{array}{l}\text { Observations, } \\
\text { interviews, } \\
\text { conversation } \\
\text { analysis }\end{array}$ & $\begin{array}{l}\text { Applying theories of the } \\
\text { language of risk to health } \\
\text { surveillance activities, } \\
\text { drawing on Hacking. }\end{array}$ & $\begin{array}{l}\text { Translating, } \\
\text { caring }\end{array}$ \\
\hline $\begin{array}{l}\text { Orleans et al. } \\
(1985)\end{array}$ & $\begin{array}{l}\text { Health Promotion in } \\
\text { Primary Care: A Survey of } \\
\text { U.S. Family Practitioners' }\end{array}$ & Family physicians & $\begin{array}{l}\text { Cigarette } \\
\text { smoking, obesity, } \\
\text { lack of exercise }\end{array}$ & USA & Survey (postal) & $\begin{array}{l}\text { No explicit framework } \\
\text { used. }\end{array}$ & Minimizing \\
\hline
\end{tabular}


Article accepted for publication in Sociology Compass 01/08/2016

\begin{tabular}{|c|c|c|c|c|c|c|c|}
\hline $\begin{array}{l}\text { Raude et al. } \\
(2004)\end{array}$ & $\begin{array}{l}\text { GPs and the social } \\
\text { amplification of BSE related } \\
\text { risk: An empirical study }\end{array}$ & General practitioners & $\begin{array}{l}\text { Bovine } \\
\text { spongiform } \\
\text { encephalopathy } \\
\text { (BSE) }\end{array}$ & France & Survey & $\begin{array}{l}\text { Social amplification of risk } \\
\text { framework. }\end{array}$ & $\begin{array}{l}\text { Translating, } \\
\text { minimizing }\end{array}$ \\
\hline $\begin{array}{l}\text { Roscigno et } \\
\text { al. (2012) }\end{array}$ & $\begin{array}{l}\text { Divergent Views of Hope } \\
\text { Influencing } \\
\text { Communications Between } \\
\text { Parents and Hospital } \\
\text { Providers }\end{array}$ & $\begin{array}{l}\text { Staff nurses, neonatal } \\
\text { nurse practitioners, } \\
\text { physicians }\end{array}$ & $\begin{array}{l}\text { Periviable delivery } \\
\text { (premature } \\
\text { infant) }\end{array}$ & USA & $\begin{array}{l}\text { Longitudinal } \\
\text { multiple case } \\
\text { study } \\
\text { investigation, } \\
\text { interviews }\end{array}$ & $\begin{array}{l}\text { No explicit framework } \\
\text { used. }\end{array}$ & $\begin{array}{l}\text { Translating, } \\
\text { caring }\end{array}$ \\
\hline $\begin{array}{l}\text { Ruston } \\
\text { (2006) }\end{array}$ & $\begin{array}{l}\text { Interpreting and managing } \\
\text { risk in a machine } \\
\text { bureaucracy: Professional } \\
\text { decision-making in NHS } \\
\text { Direct }\end{array}$ & $\begin{array}{l}\text { Nurse advisors (NHS Direct } \\
\text { - national primary care } \\
\text { telephone service) }\end{array}$ & $\begin{array}{l}\text { Range of general } \\
\text { health risks, risks } \\
\text { posed by } \\
\text { computer systems }\end{array}$ & UK & $\begin{array}{l}\text { Interviews, } \\
\text { observations, } \\
\text { secondary } \\
\text { analysis }\end{array}$ & $\begin{array}{l}\text { No explicit framework } \\
\text { used, but sensitising } \\
\text { theory provided on } \\
\text { standardizing performance } \\
\text { and reducing risk } \\
\text { associated with variation } \\
\text { in practice; and } \\
\text { frameworks of } \\
\text { professional decision } \\
\text { making and different forms } \\
\text { of knowledge deployed in } \\
\text { practice. }\end{array}$ & $\begin{array}{l}\text { Translating, } \\
\text { minimizing }\end{array}$ \\
\hline $\begin{array}{l}\text { Saïas et al. } \\
\text { (2014) }\end{array}$ & $\begin{array}{l}\text { Prevention in mental } \\
\text { health: Social } \\
\text { representations from } \\
\text { French professionals }\end{array}$ & $\begin{array}{l}\text { Mental health } \\
\text { professionals: psychiatrists, } \\
\text { psychologists, social } \\
\text { workers, nurses }\end{array}$ & Mental illness & France & $\begin{array}{l}\text { Survey - } \\
\text { including } \\
\text { open-ended } \\
\text { questions }\end{array}$ & $\begin{array}{l}\text { No explicit framework } \\
\text { used, but sensitising } \\
\text { theory provided around } \\
\text { professions and critical } \\
\text { discourses }\end{array}$ & Minimizing \\
\hline $\begin{array}{l}\text { Sarkadia et } \\
\text { al. (2004) }\end{array}$ & $\begin{array}{l}\text { The 'hows', 'whos', and } \\
\text { 'whens' of screening: } \\
\text { gynaecologists' } \\
\text { perspectives on cervical } \\
\text { cancer screening in urban } \\
\text { Sweden }\end{array}$ & Gynaecologists & $\begin{array}{l}\text { Risks of not being } \\
\text { screened for } \\
\text { cervical cancer }\end{array}$ & Sweden & $\begin{array}{l}\text { Semi- } \\
\text { structured } \\
\text { interviews }\end{array}$ & $\begin{array}{l}\text { Fourth Generation } \\
\text { Evaluation - aiming to give } \\
\text { voice to 'stakeholders' of } \\
\text { different perspectives. }\end{array}$ & $\begin{array}{l}\text { Translating, } \\
\text { minimizing }\end{array}$ \\
\hline $\begin{array}{l}\text { Scamell \& } \\
\text { Alaszewski } \\
\text { (2012) }\end{array}$ & $\begin{array}{l}\text { Fateful moments and the } \\
\text { categorisation of risk: } \\
\text { Midwifery practice and the } \\
\text { ever-narrowing window of } \\
\text { normality during childbirth }\end{array}$ & Midwives & $\begin{array}{l}\text { Potential for } \\
\text { abnormal birth } \\
\text { and risk to } \\
\text { woman or child. }\end{array}$ & UK & Ethnography & $\begin{array}{l}\text { No explicit framework } \\
\text { used, but sensitising } \\
\text { theory provided around } \\
\text { risk and normality. }\end{array}$ & $\begin{array}{l}\text { Translating, } \\
\text { minimizing }\end{array}$ \\
\hline
\end{tabular}




\begin{tabular}{|c|c|c|c|c|c|c|c|}
\hline $\begin{array}{l}\text { Scamell \& } \\
\text { Stewart } \\
(2014)\end{array}$ & $\begin{array}{l}\text { Time, risk and midwife } \\
\text { practice: the vaginal } \\
\text { examination }\end{array}$ & Midwives & $\begin{array}{l}\text { Risk of labour } \\
\text { being abnormal } \\
\text { and causing baby } \\
\text { or woman } \\
\text { harm/possible } \\
\text { death }\end{array}$ & UK & Ethnography & $\begin{array}{l}\text { No explicit framework } \\
\text { used, but sensitising } \\
\text { theory provided around } \\
\text { scientific-bureaucratic } \\
\text { systems, controlling } \\
\text { professional practice and } \\
\text { the management of } \\
\text { labour. }\end{array}$ & $\begin{array}{l}\text { Translating, } \\
\text { minimizing }\end{array}$ \\
\hline $\begin{array}{l}\text { Scamell } \\
(2011)\end{array}$ & $\begin{array}{l}\text { The swan effect in } \\
\text { midwifery talk and practice: } \\
\text { a tension } \\
\text { between normality and the } \\
\text { language of risk }\end{array}$ & Midwives & $\begin{array}{l}\text { Risk of labour } \\
\text { being abnormal } \\
\text { and causing baby } \\
\text { or woman } \\
\text { harm/possible } \\
\text { death }\end{array}$ & UK & Ethnography & $\begin{array}{l}\text { No explicit framework } \\
\text { used, but sensitising } \\
\text { theory provided on risk } \\
\text { and health surveillance. }\end{array}$ & $\begin{array}{l}\text { Translating, } \\
\text { minimizing }\end{array}$ \\
\hline $\begin{array}{l}\text { Schwennesen } \\
\text { \& Koch } \\
(2012)\end{array}$ & $\begin{array}{l}\text { Representing and } \\
\text { intervening: 'doing' good } \\
\text { care in firsttrimester } \\
\text { prenatal knowledge } \\
\text { production anddecision- } \\
\text { making }\end{array}$ & Sonographers, consultant & $\begin{array}{l}\text { Prenatal risks of } \\
\text { abnormal foetus } \\
\text { to be recognised } \\
\text { at first trimester } \\
\text { scan. Counselling } \\
\text { offered to the } \\
\text { woman, where } \\
\text { risks are also } \\
\text { discussed. }\end{array}$ & Denmark & $\begin{array}{l}\text { Ethnography } \\
\text { and } \\
\text { 'articulating } \\
\text { professional } \\
\text { self-reflection' } \\
\text { (Mol 2006) }\end{array}$ & $\begin{array}{l}\text { A constructivist approach } \\
\text { to identifying modes of } \\
\text { doing 'good care' and } \\
\text { patterns of relational } \\
\text { meaning around what } \\
\text { counts as 'good'. }\end{array}$ & $\begin{array}{l}\text { Translating, } \\
\text { minimizing, } \\
\text { caring }\end{array}$ \\
\hline Szott (2014) & $\begin{array}{l}\text { Contingencies of the will: } \\
\text { Uses of harm reduction } \\
\text { and the disease model of } \\
\text { addiction among health } \\
\text { care practitioners }\end{array}$ & $\begin{array}{l}\text { Health care practitioners } \\
\text { who provide primary care } \\
\text { and in some instances } \\
\text { buprenorphine and/or } \\
\text { methadone treatment to } \\
\text { people who inject drugs }\end{array}$ & $\begin{array}{l}\text { Harm from illegal } \\
\text { drug taking }\end{array}$ & USA & $\begin{array}{l}\text { Semi- } \\
\text { structured } \\
\text { interviews }\end{array}$ & $\begin{array}{l}\text { Post-structural theories of } \\
\text { subjectivity, including } \\
\text { feminist approaches. }\end{array}$ & $\begin{array}{l}\text { Translating, } \\
\text { minimizing, } \\
\text { caring }\end{array}$ \\
\hline $\begin{array}{l}\text { Thomas } \\
\text { (2015) }\end{array}$ & $\begin{array}{l}\text { An Elephant in the } \\
\text { Consultation Room? } \\
\text { Configuring Down } \\
\text { Syndrome in British } \\
\text { Antenatal Care }\end{array}$ & $\begin{array}{l}\text { Midwives, sonographers, } \\
\text { and other antenatal } \\
\text { healthcare professionals }\end{array}$ & $\begin{array}{l}\text { Having a baby } \\
\text { born with Down } \\
\text { Syndrome }\end{array}$ & UK & Ethnography & $\begin{array}{l}\text { Ethnomethodology - } \\
\text { attending to the mundane } \\
\text { interactions of the } \\
\text { antenatal clinic. }\end{array}$ & $\begin{array}{l}\text { Translating, } \\
\text { minimizing, } \\
\text { caring }\end{array}$ \\
\hline
\end{tabular}


Article accepted for publication in Sociology Compass 01/08/2016

\begin{tabular}{|c|c|c|c|c|c|c|c|}
\hline $\begin{array}{l}\text { Villaamil } \\
(2014)\end{array}$ & $\begin{array}{l}\text { Shared Embarrassment: } \\
\text { (Not) Talking about Sex in } \\
\text { HIV-Related Doctor-Patient } \\
\text { Encounters }\end{array}$ & HIV doctors & HIV risk reduction & Spain & Interviews & $\begin{array}{l}\text { Risk prevention and health } \\
\text { promotion seen as } \\
\text { technologies of the self. } \\
\text { Transactional model of the } \\
\text { doctor-patient } \\
\text { relationship used to } \\
\text { interpret data. }\end{array}$ & $\begin{array}{l}\text { Translating, } \\
\text { minimizing }\end{array}$ \\
\hline $\begin{array}{l}\text { Wardlow } \\
(2012)\end{array}$ & $\begin{array}{l}\text { The Task of the HIV } \\
\text { Translator: Transforming } \\
\text { Global AIDS Knowledge in } \\
\text { an Awareness Workshop }\end{array}$ & AIDS awareness educators & $\begin{array}{l}\text { Sexual } \\
\text { health/HIV-AIDS } \\
\text { prevention }\end{array}$ & $\begin{array}{l}\text { Papua New } \\
\text { Guinea }\end{array}$ & $\begin{array}{l}\text { Textual and } \\
\text { observational } \\
\text { data }\end{array}$ & $\begin{array}{l}\text { Anthropological theories } \\
\text { of the labour of policy } \\
\text { implementation and } \\
\text { translation, and actor- } \\
\text { network theory. }\end{array}$ & Translating \\
\hline $\begin{array}{l}\text { Warner \& } \\
\text { Gabe (2004) }\end{array}$ & $\begin{array}{l}\text { Risk and liminality in mental } \\
\text { health social work }\end{array}$ & $\begin{array}{l}\text { Mental health social } \\
\text { workers }\end{array}$ & $\begin{array}{l}\text { Mental illness and } \\
\text { personality } \\
\text { disorder }\end{array}$ & UK & $\begin{array}{l}\text { Semi- } \\
\text { structured } \\
\text { interviews }\end{array}$ & $\begin{array}{l}\text { Socio-cultural concepts of } \\
\text { 'otherness' in relation to } \\
\text { professional practice. } \\
\text { Authors develop concept } \\
\text { of liminal otherness. }\end{array}$ & $\begin{array}{l}\text { Translating, } \\
\text { minimizing }\end{array}$ \\
\hline $\begin{array}{l}\text { Warner } \\
(2006)\end{array}$ & $\begin{array}{l}\text { Inquiry reports as active } \\
\text { texts and their function in } \\
\text { relation to professional } \\
\text { practice in mental health }\end{array}$ & $\begin{array}{l}\text { Social workers \& their } \\
\text { managers }\end{array}$ & $\begin{array}{l}\text { Service users at } \\
\text { risk of committing } \\
\text { homicide }\end{array}$ & UK & $\begin{array}{l}\text { Semi- } \\
\text { structured } \\
\text { interviews }\end{array}$ & $\begin{array}{l}\text { Concept of the 'active text' } \\
\text { as structuring social } \\
\text { relations. }\end{array}$ & $\begin{array}{l}\text { Translating, } \\
\text { minimizing }\end{array}$ \\
\hline $\begin{array}{l}\text { Williams et } \\
\text { al. (2002) }\end{array}$ & $\begin{array}{l}\text { 'Drawing the line' in pre- } \\
\text { natal screening and testing: } \\
\text { Health practitioners' } \\
\text { discussions }\end{array}$ & $\begin{array}{l}\text { Prenatal screening health } \\
\text { practitioners: midwives; } \\
\text { health visitors; neonatal } \\
\text { nurses; genetic counsellors; } \\
\text { sonographers;obstetricians; } \\
\text { foetal medicine specialists; } \\
\text { haematologists; } \\
\text { paediatricians; } \\
\text { psychologists; } \\
\text { chaplains;and legal, audit } \\
\text { and primary care } \\
\text { managers. }\end{array}$ & $\begin{array}{l}\text { Prenatal } \\
\text { screening for } \\
\text { genetic conditions } \\
\text { and diseases }\end{array}$ & UK & $\begin{array}{l}\text { Interviews and } \\
\text { focus groups }\end{array}$ & $\begin{array}{l}\text { No explicit framework } \\
\text { used, but sensitising } \\
\text { theory provided on the } \\
\text { problems of 'line drawing' } \\
\text { within screening, locating } \\
\text { this within broader } \\
\text { debates around the politics } \\
\text { of disability and medical } \\
\text { ethics. }\end{array}$ & $\begin{array}{l}\text { Translating, } \\
\text { minimizing, } \\
\text { caring }\end{array}$ \\
\hline
\end{tabular}


Article accepted for publication in Sociology Compass 01/08/2016

\begin{tabular}{|c|c|c|c|c|c|c|c|}
\hline $\begin{array}{l}\text { Wood et al. } \\
(2003)\end{array}$ & $\begin{array}{l}\text { Translations of risk: } \\
\text { Decision making in a cancer } \\
\text { genetics service }\end{array}$ & $\begin{array}{l}\text { Health professionals } \\
\text { working within a (cancer) } \\
\text { genetics unit }\end{array}$ & $\begin{array}{l}\text { Risk of hereditary } \\
\text { cancer: } \\
\text { practitioners must } \\
\text { make decisions on } \\
\text { level of risk and } \\
\text { whether they } \\
\text { further } \\
\text { investigate a } \\
\text { person, based on } \\
\text { GP referral } \\
\text { letters. }\end{array}$ & UK & Ethnography & $\begin{array}{l}\text { Phenomenology, and } \\
\text { sensitising theory provided } \\
\text { on clinical decision making }\end{array}$ & $\begin{array}{l}\text { Translating, } \\
\text { minimizing }\end{array}$ \\
\hline $\begin{array}{l}\text { Zayts \& } \\
\text { Sarangi } \\
(2013)\end{array}$ & $\begin{array}{l}\text { Modes of risk explanation in } \\
\text { telephone consultations } \\
\text { between nurses and } \\
\text { parents for a genetic } \\
\text { condition }\end{array}$ & $\begin{array}{l}\text { Genetic nurses (and } \\
\text { patients' parents) }\end{array}$ & $\begin{array}{l}\text { Risk of children } \\
\text { having a genetic } \\
\text { condition } \\
\text { (favism): nurses } \\
\text { explaining this } \\
\text { risk to patients' } \\
\text { parents }\end{array}$ & Hong Kong & $\begin{array}{l}\text { Semi- } \\
\text { structured } \\
\text { interviews } \\
\text { (telephone } \\
\text { and face-to- } \\
\text { face) }\end{array}$ & $\begin{array}{l}\text { No explicit framework } \\
\text { used, but sensitising } \\
\text { theory provided on risk, } \\
\text { decision-making, and } \\
\text { interactions between } \\
\text { professionals and } \\
\text { patients/clients. }\end{array}$ & $\begin{array}{l}\text { Translating, } \\
\text { caring }\end{array}$ \\
\hline
\end{tabular}


Article accepted for publication in Sociology Compass 01/08/2016

\section{Contributions to the paper}

NG and PB developed the conceptual basis of the review and GT and SG were involved in shaping the project. The searches were conducted by NG and RT, with assistance from two specialist librarians from the Health Services Management Centre, Rachel Posaner and Emma Green. RT conducted the hand searches and targeted searches of the journals identified as priority journals. Data extraction was primarily undertaken by $\mathrm{RT}$, but each author extracted data, including the first and second order interpretations, for at least 2 papers. All authors contributed to the analysis and synthesis. All authors contributed to writing the article and approved the final version.

\section{Biographical statement}

Nicola Gale is health sociologist primarily focused on professional practice and workforce development in public health, primary, community and complementary health care. Gareth Thomas is a sociologist who is interested in - among other things - medicine, disability, social stigma, health and wellbeing, genetics, parenthood, and reproduction. Rachel Thwaites is a sociologist of gender, health, identities, and higher education, with interests in qualitative and innovative methods. Sheila Greenfield is a medical sociologist and qualitative methodologist with research interests in how people self- manage their health either for health promotion and prevention or to manage diagnosed medical conditions. Patrick Brown is a sociologist interested in experiences of uncertainty within healthcare contexts and various processes by which uncertainty is 'handled', for example risk, trust and hope.

\section{References:}

Alaszewski, A. and P. Brown (2007). "Risk, uncertainty and knowledge." Health, Risk \& Society 9(1): 1-10. Anderson, G. (1999). "Nondirectiveness in prenatal genetics: patients read between the lines." Nursing Ethics 6(2): 126-136.

Armstrong, D. (2007). "Professionalism, indeterminacy and the EBM project." BioSocieties 2(1): 73-84.

Arribas-Ayllon, M. and S. Sarangi (2014). "Counselling uncertainty: genetics professionals' accounts of (non) directiveness and trust/distrust." Health, risk \& society 16(2): 171-184.

Bardach, S. H. and N. E. Schoenberg (2012). "Primary care physicians' prevention counseling with patients with multiple morbidity." Qualitative health research 22(12): 1599-1611.

Bean, S. J. and J. A. Catania (2013). "Vaccine perceptions among Oregon health care providers." Qualitative health research 23(9): 1251-1266.

Beck, U. (1992). Risk society: Towards a new modernity. London, Sage.

Beck, U. (2000). "Risk society revisited: theory, politics and research programmes." The risk society and beyond: Critical issues for social theory: 211-229.

Benoit, C., C. Stengel, L. Marcellus, H. Hallgrimsdottir, J. Anderson, K. MacKinnon, R. Phillips, P. Zazueta and S. Charbonneau (2014). "Providers' constructions of pregnant and early parenting women who use substances." Sociology of health \& illness 36(2): 252-263. 
Boardman, F. (2014). "Experiential knowledge of disability, impairment and illness: The reproductive decisions of families genetically at risk." Health: 18(5): 476-492.

Bodenheimer, T., K. Lorig, H. Holman and K. Grumbach (2002). "Patient self-management of chronic disease in primary care." Jama 288(19): 2469-2475.

Broom, A. and J. Adams (2009). "Oncology clinicians' accounts of discussing complementary and alternative medicine with their patients." Health: 13(3): 317-336.

Broom, A., J. Broom and E. Kirby (2014). "Cultures of resistance? A Bourdieusian analysis of doctors' antibiotic prescribing." Social Science \& Medicine 110: 81-88.

Broom, A. F. and A. Doron (2013). "Traditional medicines, collective negotiation, and representations of risk in Indian cancer care." Qualitative health research 23(1): 54-65.

Brown, P. and M. Calnan (2013). "Trust as a means of bridging the management of risk and the meeting of need: a case study in mental health service provision." Social Policy \& Administration 47(3): 242-261.

Brown, P. R., A. Alaszewski, T. Swift and A. Nordin (2011). "Actions speak louder than words: the embodiment of trust by healthcare professionals in gynae-oncology." Sociology of Health \& Illness 33(2): 280-295.

Brown, P. R. and M. W. Calnan (2015). "Chains of (dis) trust: exploring the underpinnings of knowledgesharing and quality care across mental health services." Sociology of Health \& Illness.

Burton-Jeangros, C., S. Cavalli, S. Gouilhers and R. Hammer (2013). "Between tolerable uncertainty and unacceptable risks: how health professionals and pregnant women think about the probabilities generated by prenatal screening." Health, risk \& society 15(2): 144-161.

Cabral, C., P. J. Lucas, J. Ingram, A. D. Hay and J. Horwood (2015). "“It's safer to..." parent consulting and clinician antibiotic prescribing decisions for children with respiratory tract infections: An analysis across four qualitative studies." Social Science \& Medicine 136: 156-164.

Castel, R. (1991). From dangerousness to risk. The Foucault Effect: Studies in Governmentality. G. Burchell, C. Gordon and P. M. (eds). Hemel Hempstead, Haverster Wheatsheaf: 281-298.

Cricco-Lizza, R. (2010). "Everyday nursing practice values in the NICU and their reflection on breastfeeding promotion." Qualitative health research 21(3): 399-409.

Darroch, F. E. and A. R. Giles (2015). "Health/Service Providers' Perspectives on Barriers to Healthy Weight Gain and Physical Activity in Pregnant, Urban First Nations Women." Qualitative health research: 1049732315576497.

Davis, M., P. Flowers and N. Stephenson (2014). "'We had to do what we thought was right at the time': retrospective discourse on the 2009 H1N1 pandemic in the UK." Sociology of health \& illness 36(3): 369-382. Davison, C., G. D. Smith and S. Frankel (1991). "Lay epidemiology and the prevention paradox: the implications of coronary candidacy for health education." Sociology of Health \& Illness 13(1): 1-19.

Delawarde, C., T. Saïas and X. Briffault (2014). "The public health dogma of evidence-based mental disorders prevention and mental health promotion: French professionals' beliefs in regard to parenting programs." Health Sociology Review 23(3): 166-177.

Douglas, M. (1992). Risk and Blame: Essays in Cultural Theory. London, Routledge.

Flynn, R. (2002). "Clinical governance and governmentality." Health, Risk \& Society 4(2): 155-173.

Fox, R. C. (1980). "The evolution of medical uncertainty." The Milbank Memorial Fund Quarterly. Health and Society: $1-49$.

Fox, R. C. (2002). Medical Uncertainty Revisited. Gender, health and healing: the public/private divide. G. Bendelow, M. Carpenter, C. Vautier and S. Williams. London, Routledge.

Frohlich, K. L., E. Mykhalovskiy, B. D. Poland, R. Haines-Saah and J. Johnson (2012). "Creating the socially marginalised youth smoker: the role of tobacco control." Sociology of health \& illness 34(7): 978-993.

Gale, N. K. (2011). "From body-talk to body-stories: body work in complementary and alternative medicine." Sociology of Health \& Illness 33(2): 237-251.

Gale, N. K., S. Greenfield, P. Gill, K. Gutridge and T. Marshall (2011). "Patient and general practitioner attitudes to taking medication to prevent cardiovascular disease after receiving detailed information on risks and benefits of treatment: a qualitative study." BMC Family Practice 12(1): 59.

Giddens, A. (1991). Modernity and self-identity: Self and society in the late modern age. CA, Stanford University Press.

Gillespie, C. (2012). "The experience of risk as 'measured vulnerability': health screening and lay uses of numerical risk." Sociology of health \& illness 34(2): 194-207. 
Godin, P. (2004). "'You don't tick boxes on a form': A study of how community mental health nurses assess and manage risk." Health, Risk \& Society 6(4): 347-360.

Green, E. E., D. Thompson and F. Griffiths (2002). "Narratives of Risk: women at midlife, medical'experts' and health technologies." Health, risk \& society 4(3): 273-286.

Griffiths, F., E. Green and G. Bendelow (2006). "Health professionals, their medical interventions and uncertainty: A study focusing on women at midlife." Social Science \& Medicine 62(5): 1078-1090.

Hall, W. A., J. Tomkinson and M. C. Klein (2012). "Canadian care providers' and pregnant women's approaches to managing birth minimizing risk while maximizing integrity." Qualitative health research 22(5): 575-586.

Hallowell, N. (1999). "Doing the right thing: genetic risk and responsibility." Sociology of Health \& Illness 21(5): 597-621.

Henwood, K., N. Pidgeon, K. Parkhill and P. Simmons (2011). "Researching Risk: Narrative, Biography, Subjectivity." Historical Social Research / Historische Sozialforschung 36(4 (138)): 251-272.

Hernandez, E. M. (2013). "Provider and patient influences on the formation of socioeconomic health behavior disparities among pregnant women." Social Science \& Medicine 82: 35-42.

Herron, J., H. Ticehurst, L. Appleby, A. Perry and L. Cordingley (2001). "Attitudes Toward Suicide Prevention in Front-Line Health Staff." Suicide and Life-Threatening Behavior 31(3): 342-347.

Hindhede, A. L. (2014). "Prediabetic categorisation: the making of a new person." Health, Risk \& Society 16(78).

Hood, C., H. Rothstein and R. Baldwin (2001). The government of risk: Understanding risk regulation regimes. Oxford, Oxford University Press.

Horlick-Jones, T. (2005). "On 'risk work': professional discourse, accountability, and everyday action." Health, risk \& society 7(3): 293-307.

Iversen, C. (2014). "Predetermined participation Social workers evaluating children's agency in domestic violence interventions." Childhood 21(2): 274-289.

Jamous, H. and B. Peloille (1970). "Professions or self-perpetuating systems? Changes in the French university-hospital system. Professions and Professionalization. JA Jackson." Cambridge, Cambridge at the University Press 3: 111-152.

Järvinen, M. (2012). "A will to health? Drinking, risk and social class." Health, risk \& society 14(3): 241-256. Johnson, C. D., J. Noyes, A. Haines, K. Thomas, C. Stockport, A. N. Ribas and M. Harris (2013). "Learning from the Brazilian community health worker model in North Wales." Globalization and health 9(25): 10.1186.

Kemshall, H. (2002). Risk, Social Policy and Welfare. Buckingham, Open University Press.

Kirk, S. F., S. L. Price, T. L. Penney, L. Rehman, R. F. Lyons, H. Piccinini-Vallis, T. M. Vallis, J. Curran and M. Aston (2014). "Blame, shame, and lack of support a multilevel study on obesity management." Qualitative health research: 1049732314529667.

Kreiner, M. J. and L. M. Hunt (2014). "The pursuit of preventive care for chronic illness: turning healthy people into chronic patients." Sociology of health \& illness 36(6): 870-884.

Lankshear, G., E. Ettorre and D. Mason (2005). "Decision-making, uncertainty and risk: Exploring the complexity of work processes in NHS delivery suites." Health, risk \& society 7(4): 361-377.

Lewin, S., S. Munabi-Babigumira, C. Glenton, K. Daniels, X. Bosch-Capblanch, B. E. van Wyk, J. OdgaardJensen, M. Johansen, G. N. Aja and M. Zwarenstein (2010). "Lay health workers in primary and community health care for maternal and child health and the management of infectious diseases." The Cochrane Library 17(3).

Lorig, K. (2002). "Partnerships between expert patients and physicians." The Lancet 359(9309): 814-815.

Lupton, D. and J. Tulloch (2002). "Risk is part of your life': Risk epistemologies among a group of Australians." Sociology 36(2): 317-334.

MacLeod, H. and R. L. Stadnyk (2015). "Risk:'I know it when I see it': how health and social practitioners defined and evaluated living at risk among community-dwelling older adults." Health, Risk \& Society 17(1): 46-63.

Maconachie, M. and G. Lewendon (2004). "Immunising Children in Primary Care in the UK-What are the Concerns of Principal Immunisers?" Health Education Journal 63(1): 40-49.

McCourt, C. (2006). "Supporting choice and control? Communication and interaction between midwives and women at the antenatal booking visit." Social science \& medicine 62(6): 1307-1318. 
Mishra, A. and J. E. Graham (2012). "Risk, choice and the 'girl vaccine': Unpacking human papillomavirus (HPV) immunisation." Health, Risk \& Society 14(1): 57-69.

Murtagh, M. J. and J. Hepworth (2003). "Menopause as a long-term risk to health: implications of general practitioner accounts of prevention for women's choice and decision-making." Sociology of health \& illness 25(2): 185-207.

Nading, A. M. (2013). "Love Isn't There in Your Stomach." Medical anthropology quarterly 27(1): 84-102.

NHS England (2014). Five Year Forward View. London, NHS England.

Nissen, N. (2013). "Women's Bodies and Women's Lives in Western Herbal Medicine in the UK." Medical anthropology 32(1): 75-91.

Olin Lauritzen, S. and L. Sachs (2001). "Normality, risk and the future: implicit communication of threat in health surveillance." Sociology of health \& illness 23(4): 497-516.

Orleans, C. T., L. K. George, J. L. Houpt and K. H. Brodie (1985). "Health promotion in primary care: a survey of US family practitioners." Preventive medicine 14(5): 636-647.

Petersen, A. (1997). Risk, governance and the new public health. Foucault, health and medicine. A. Petersen and R. Bunton. London, Routledge: 189-206.

Petersen, A. and D. Lupton (1996). The new public health: Health and self in the age of risk, Sage Publications, Inc.

Pettinger, L., J. Parry, R. Taylor and M. Glucksmann (2006). A new sociology of work?, Wiley-Blackwell.

Pilnick, A. (2008). "It's something for you both to think about': choice and decision making in nuchal translucency screening for Down's syndrome." Sociology of health \& illness 30(4): 511-530.

Pilnick, A. and O. Zayts (2012). "'Let's have it tested first': choice and circumstances in decision-making following positive antenatal screening in Hong Kong." Sociology of health \& illness 34(2): 266-282.

Power, M. (2004). The Risk Management of Everything: Rethinking the Politics of Uncertainty. London, Demos.

Raude, J., C. Fischler, E. Lukasiewicz, M. Setbon and A. Flahault (2004). "GPs and the social amplification of BSE-related risk: An empirical study." Health, Risk \& Society 6(2): 173-185.

Roscigno, C. I., T. A. Savage, K. Kavanaugh, T. T. Moro, S. J. Kilpatrick, H. T. Strassner, W. A. Grobman and R. E. Kimura (2012). "Divergent views of hope influencing communications between parents and hospital providers." Qualitative health research 22(9): 1232-1246.

Rothstein, H. (2006). "The institutional origins of risk: A new agenda for risk research."

Ruston, A. (2006). "Interpreting and managing risk in a machine bureaucracy: Professional decision-making in NHS Direct." Health, risk \& society 8(3): 257-271.

Saïas, T., L. Véron, C. Delawarde and X. Briffault (2014). "Prevention in mental health: Social representations from French professionals." Health Sociology Review 23(2): 159-164.

Sarkadia, A., C. Widmark, S. Törnberg and C. Tishelman (2004). "The 'hows', 'whos', and 'whens' of screening: gynaecologists' perspectives on cervical cancer screening in urban Sweden." Social science \& medicine 58(6): 1097-1108.

Scamell, M. (2011). "The swan effect in midwifery talk and practice: a tension between normality and the language of risk." Sociology of health \& illness 33(7): 987-1001.

Scamell, M. and A. Alaszewski (2012). "Fateful moments and the categorisation of risk: Midwifery practice and the ever-narrowing window of normality during childbirth." Health, risk \& society 14(2): 207-221.

Scamell, M. and M. Stewart (2014). "Time, risk and midwife practice: the vaginal examination." Health, risk \& society 16(1): 84-100.

Schwennesen, N. and L. Koch (2012). "Representing and intervening:'doing'good care in first trimester prenatal knowledge production and decision-making." Sociology of health \& illness 34(2): 283-298.

Secretary of State for Health (2008). High Quality Care for All: NHS Next Stage Review Final Report, The Stationery Office.

Singh, P. and D. A. Chokshi (2013). "Community health workers-a local solution to a global problem." New England Journal of Medicine 369(10): 894-896.

Singh, P. and J. D. Sachs (2013). "1 million community health workers in sub-Saharan Africa by 2015." The Lancet 382(9889): 363-365. 
Article accepted for publication in Sociology Compass 01/08/2016

Snow, R., C. Humphrey and J. Sandall (2013). "What happens when patients know more than their doctors? Experiences of health interactions after diabetes patient education: a qualitative patient-led study." BMJ Open 3(11).

Strauss, A. L., S. Y. Fagerhaugh, B. Suczek and C. Wiener (2014[1985]). Social organization of medical work. NJ, Transaction Publishers.

Szott, K. (2014). "Contingencies of the will: Uses of harm reduction and the disease model of addiction among health care practitioners." Health:: 1363459314556904.

Tanenbaum, S. J. (1994). "Knowing and acting in medical practice: the epistemological politics of outcomes research." Journal of Health Politics, Policy and Law 19(1): 27-44.

Thomas, G. M. (2014). "Prenatal Screening for Down's Syndrome: Parent and Healthcare Practitioner Experiences." Sociology Compass 8(6): 837-850.

Thomas, G. M. (2015). "An Elephant in the Consultation Room?: Configuring Down Syndrome in British Antenatal Care." Medical anthropology quarterly.

Thomas, G. M. and J. Latimer (2015). "In/Exclusion in the Clinic: Down's Syndrome, Dysmorphology and the Ethics of Everyday Medical Work." Sociology 49(5): 937-954.

Timmermans, S. and M. Buchbinder (2010). "Patients-in-waiting living between sickness and health in the genomics era." Journal of Health and Social Behavior 51(4): 408-423.

Traynor, M. (2009). "Indeterminacy and technicality revisited: how medicine and nursing have responded to the evidence based movement." Sociology of health \& illness 31(4): 494-507.

Tsouroufli, M. (2011). "Routinisation and constraints on informed choice in a one-stop clinic offering first trimester chromosomal antenatal screening for Down's syndrome." Midwifery 27(4): 431-436.

Twigg, J., C. Wolkowitz, R. L. Cohen and S. Nettleton (2011). "Conceptualising body work in health and social care." Sociology of Health \& Illness 33(2): 171-188.

van Loon, J. (2014). "Remediating risk as matter-energy-information flows of avian influenza and BSE." Health, Risk \& Society 16(5): 444-458.

Villaamil, F. (2014). "Shared Embarrassment:(Not) Talking about Sex in HIV-Related Doctor-Patient Encounters." Medical anthropology 33(4): 335-350.

Wardlow, H. (2012). "The Task of the HIV Translator: Transforming Global AIDS Knowledge in an Awareness Workshop." Medical anthropology 31(5): 404-419.

Warner, J. (2006). "Inquiry reports as active texts and their function in relation to professional practice in mental health." Health, risk \& society 8(3): 223-237.

Warner, J. and J. Gabe (2004). "Risk and liminality in mental health social work." Health, risk \& society 6(4): 387-399.

Williams, C., P. Alderson and B. Farsides (2002). "Dilemmas encountered by health practitioners offering nuchal translucency screening: a qualitative case study." Prenatal Diagnosis 22(3): 216-220.

Williams, C., P. Alderson and B. Farsides (2002). "'Drawing the line'in prenatal screening and testing: Health practitioners' discussions." Health, Risk \& Society 4(1): 61-75.

Williams, C., J. Sandall, G. Lewando-Hundt, B. Heyman, K. Spencer and R. Grellier (2005). "Women as moral pioneers? Experiences of first trimester antenatal screening." Social science \& medicine 61(9): 1983-1992.

Wolf, E. R. (1956). "Aspects of group relations in a complex society: Mexico." American Anthropologist 58(6): 1065-1078.

Wolkowitz, C. (2006). Bodies at work, Sage.

Wood, F., L. Prior and J. Gray (2003). "Translations of risk: decision making in a cancer genetics service." Health, risk \& society 5(2): 185-198.

Zayts, O. and S. Sarangi (2013). "Modes of risk explanation in telephone consultations between nurses and parents for a genetic condition." Health, Risk \& Society 15(2): 194-215.

Zinn, J. O. (2008). "Heading into the unknown: Everyday strategies for managing risk and uncertainty." Health, risk \& society 10(5): 439-450. 